\title{
EXPERIMENTAL VALIDATION
}

\section{OF THE GEARBOX NVH PARAMETERS}

\section{ALEŠ PROKOP, KAMIL ŘEHÁK, MARTIN ZUBÍK, PAVEL NOVOTNÝ}

Brno University of Technology, Technická 2, CZ 61669 Brno, Czech Republic

Tel.: +420 541142 266, Email: prokop.a@fme.vutbr.cz

\section{SHRNUTI}

Vibrace a hluk převodových ústrojí jsou významným tématem nejen v automobilovém průmyslu. Pro správné pochopení různých zákonitostí ovlivňujících dynamické vlastnosti převodovek je nezbytné se nejdříve zabývat zjednodušeným případem, $\mathrm{s}$ jeho pomocí vytvořit vhodnou výpočtovou metodiku a výsledky následně validovat technickým experimentem. Celý postup pak může být posléze aplikován na složitější prevodovku spolu s opětovnou validací modelu. V článku je popsána tvorba zjednodušeného výpočtového modelu převodovky, který zahrnuje všechny klíčové mechanismy jako např. proměnnou tuhost ozubení, zubovou vưli, tuhost ložisek a modální vlastnosti hlavních komponent. Spolu s prezentovaným výpočtovým modelem je užito i dalších dílčích modelů, o různé úrovni popisu fyzikálních dějů. Výsledky numerického řešení všech výpočtových modelů jsou porovnány s měřením s dobrou korelací.

\section{KLIČCVÁ SLOVA: PŘEVODOVKA, VIBRACE, HLUK, TUHOST OZUBENÍ, MĚŘENÍ}

\section{ABSTRACT}

The noise, vibration and harshness (NVH) plays an important role in the transmission area of automotive industry. To understand all the impacts on the gearbox's global dynamic behavior it is necessary to gain information from a simplified model, create methods and get an appropriate and well correlated results with the experiment. The method itself can be afterwards reused for more complex transmission, which could be supported by other measurements. This paper deals with creation of a gearbox's simplified model, including essential mechanisms as gear mesh stiffness, backlash, bearing stiffness and modal properties of the main components. Except for the presented model, more models with different difficulty levels are used. Numerical results are compared with data from experiment with good correlation.

KEYWORDS: TRANSMISSION, VIBRATION, NOISE, GEAR MESH STIFFNESS, EXPERIMENT

\section{INTRODUCTION}

Nowadays, the NVH problem is a very actual issue in the automotive industry. On the one hand, vehicles of the same class, by different producers, are much more similar than they used to be. The differences are mostly in design section, price and also in the overall acoustic expression which corresponds with the perceived comfort level. Secondly, future strict noise regulations in this area, which are about to be enforced, pressure the companies to integrate NVH investigation into the development process.

The most time-consuming approach, when dealing with the transmission $\mathrm{NVH}$, is to use experiments to acquire promising results, especially due to manufacturing so many prototypes. Because of that, numerical simulations are widely used to predict at least basic gearbox's dynamic behavior. Measurement techniques are necessary for the validation of simulation results [1]. At the beginning it is necessary to test the simulation process. It means to establish methodology on the real transmission and validate all the simulation steps by an appropriate experiment. Therefore, a singlestage gearbox with the simplified body is designed and the whole measurement process is examined on this transmission unit [1].

The similar concept of the single stage gearbox is used in [2], where the artificially induced gear crack contribution for the overall dynamic behavior is investigated. Simplified housing for this kind of analysis seems to be necessary. Shape diversity usually means higher number of the supporting parts and their undefined excitations can influence the sensitivity analysis. Another similar utilization of a simplified gearbox for the bearings behavior observation is presented in [3]. 
Other important NVH sensitivity analyses concern gears as well. Work described in [4] focuses on the gearbox rattle phenomenon. Rattle itself is a very complex issue which typically occurs when the gears are unloaded and can knock each other under special conditions. Moreover, these conditions, as gear pair clearance, inertia or stiffness parameters, are significant for the global transmission dynamics as well [5]. Also the changes in the natural frequencies due to the external loading and gear meshing can be seen in [6].

The aim of this paper is to present a complex approach for gearbox $\mathrm{NVH}$ parameters and also to come up with a full experimental validation to support the computational model correctness.

\section{MULTI-BODY MODEL}

Computational model of the transmission should cover as many operational aspects as possible [7]. When considering all the transient conditions that can occur, multi-body (MBS) based models can be efficiently used for a solution in time domain. Except the benefits, it takes a lot of effort to put the gearbox assembly together and ensure the proper model behavior. Incorporation of the flexible bodies and correct stiffness and damping estimation is essential. These values can spread up to several decimal points. Therefore, the experimental validation is necessary as the main output verification factor.

\subsection{MBS MODEL ASSEMBLY BACKGROUND}

The multibody approach is very useful for predicting dynamics interaction between all the assembly subcomponents. Gearbox assembly is in this way, represented predominantly by the gear pair contacts, shafts, bearings and housing body. Even though all the parts seem to be simple, there are several principles how to deal with their MBS condensation.

At first, global parts like shaft and housing need to be considered as flexible. For that reason Craig Bampton (CB) principle [8] of the FE model reduction is utilized. This procedure replaces real deformations contained in the basic equation of motion form by the simplified approximation established from the two variants of degrees of freedom multiplied by the special Craig-Bampton transform matrix, see equation 1 ; [8]:

$$
\left\{\mathbf{u}_{A}\right\}=\left\{\begin{array}{l}
\mathbf{u}_{b} \\
\mathbf{u}_{L}
\end{array}\right\}=\left[\begin{array}{cc}
\mathbf{I} & \mathbf{0} \\
\boldsymbol{\Phi}_{R} & \boldsymbol{\Phi}_{L}
\end{array}\right]\left\{\begin{array}{c}
\mathbf{u}_{b} \\
\mathbf{q}
\end{array}\right\}=\boldsymbol{\Phi}_{C B}\left\{\begin{array}{c}
\mathbf{u}_{b} \\
\mathbf{q}
\end{array}\right\},
$$

where $u_{A}$ is the original vector of deformation, $u_{b}$ are the boundary degrees of freedom (DOFs), $q$ represents modal
DOFs, $I$ is the unit matrix element, $\phi_{R}$ is rigid body matrix element and in the analogical way $\phi_{L}$ is the fixed base mode shapes matrix element.

After incorporation of this basic approximation in the motion equation and also mass and stiffness matrices transformation the final equation of motion can be defined as [8]:

$$
\begin{aligned}
& {\left[\begin{array}{cc}
\mathbf{M}_{b b} & \mathbf{M}_{b q} \\
\mathbf{M}_{q b} & \mathbf{I}
\end{array}\right]\left\{\begin{array}{c}
\ddot{\mathbf{u}}_{b} \\
\ddot{\mathbf{q}}
\end{array}\right\}+\left[\begin{array}{cc}
\mathbf{0} & \mathbf{0} \\
\mathbf{0} & \mathbf{2 \zeta \boldsymbol { \omega }}
\end{array}\right]\left\{\begin{array}{c}
\dot{\mathbf{u}}_{b} \\
\dot{\mathbf{q}}
\end{array}\right\}+} \\
& +\left[\begin{array}{cc}
\mathbf{K}_{b b} & \mathbf{0} \\
\mathbf{0} & \boldsymbol{\omega}^{2}
\end{array}\right]\left\{\begin{array}{c}
\mathbf{u}_{b} \\
\mathbf{q}
\end{array}\right\}=\{\mathbf{F}(\mathbf{t})\},
\end{aligned}
$$

where $2 \zeta \omega$ means modal damping as a percentage of the critical damping expressed by $\zeta$. Then indexes among mass and stiffness matrices distinguish between boundary (rigid) modes and fixed normal modes (internal, leftover) DOFs.

A summarized basic idea of the $C B$ reduction is that the assembly parts are modeled independently and their internal dynamic behavior is represented by the natural vibration modes. This approach works well when the physical connections between each part are simple regarding the internal dynamics. Consequently, the couplings in form of bearings stiffness and damping have constant or linear functions [9]. This restriction is valid when the focus is put on the global behavior and not the bearing dynamics for instance.

\subsection{SIN GLE-STAGE GEARBOX MBS MODEL}

As mentioned previously, single stage gearbox is created for the verification of model principles and also for further validation by a proper experiment. Input FE data entering

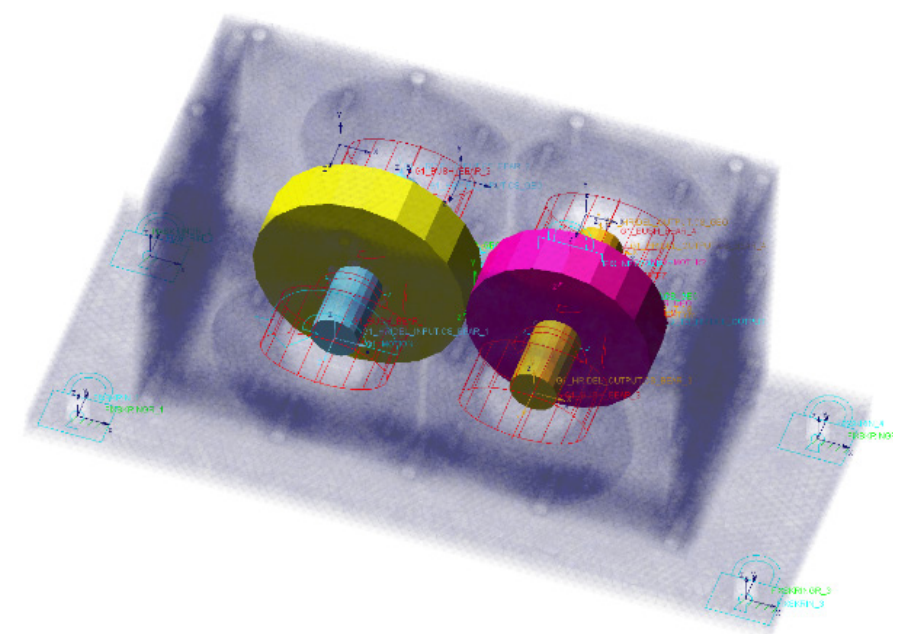

FIGURE 1: Experimental gearbox MBS model view OBRÁZEK 1: MBS model experimentální převodovky 


\section{Variable gear mesh stiffness}
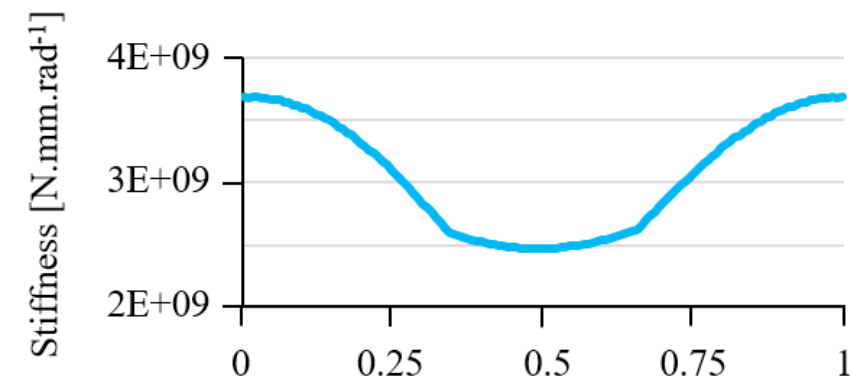

Gear angle period [-]

OBRÁZEK 2: Průběh proměnné tuhosti ozubení u kontaktu kol se šikmými zuby

FIGURE 2: Variable mesh stiffness of the helical gear contact

the MBS assembly are validated firstly as single components through the modal and harmonic analysis. This is concerning mostly the gearbox housing on which the final NVH output, i.e. surface normal velocity, is observed.

Dealing with the housing separately is convenient for setting the modal shapes natural frequencies. These frequencies are then entering the $C B$ reduction and can significantly influence the overall housing dynamic behavior. This kind of study applied to the real automotive gearbox is presented in [10]. Also the estimated damping is validated and approximated to the real state conditions.

Presented MBS gearbox model covers the gear pair contact connected to the flexible shafts which are assembled in the gearbox housing. Stiffness and damping characteristics of the situated joints (tappered roller bearings) are included, as well, in form of the FE calculation. View of the model is in the Figure 1.

The gearbox itself consists of the steel bonded housing with four holes for the tapered roller bearings which support the input and the output shaft. The input shaft also includes simple plastic torsional dumper to secure a minimum influence form the powering side. Material of the housing and shafts is a common structural steel class S235JR, gears are made of the $20 \mathrm{CrMo} 4$ carbon steel with the number of teeth 31 and 27. The material aspect influence on the modal analysis presented in the [11] shows the difference in natural frequencies hundreds of hertz when comparing grey cast iron and structural steel. Therefore, a proper material definition of the model's parts is an essential step. Measured results of the modal properties and also harmonic loading motion response are very close to the numerical simulation, so the correlation up to $2 \%$ in frequency variance is affirmed.

The fundamental part of the MBS model is gear mesh contact which is the main excitation source [12]. It is due to a dissimilar load coming from the variable gear pair stiffness which is based on the number of acting teeth in contact. Some simplified definitions of this contact based on linear or sinusoidal functions exist but nowadays a precise computations are conducted more often [13, 14]. Therefore, the sinusoidal function used in the case of helical gears contact is replaced by the real behavior computed by using an exact FE model, as shown in the Figure 2.

Even though the shown curve in the Figure 2 is close to the sinusoidal function, in fact it represents active gear profile acting during the contact period. Tooth profile is simulated by

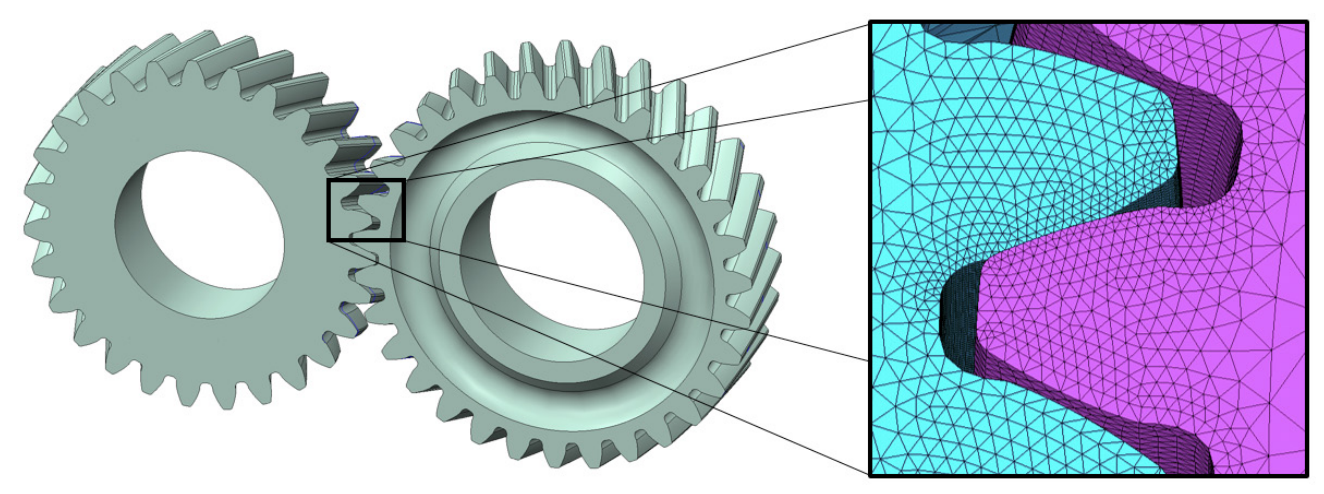

FIGURE 3: Detail of the teeth profiles

OBRÁZEK 3: Detailní zobrazení profilu zubů 


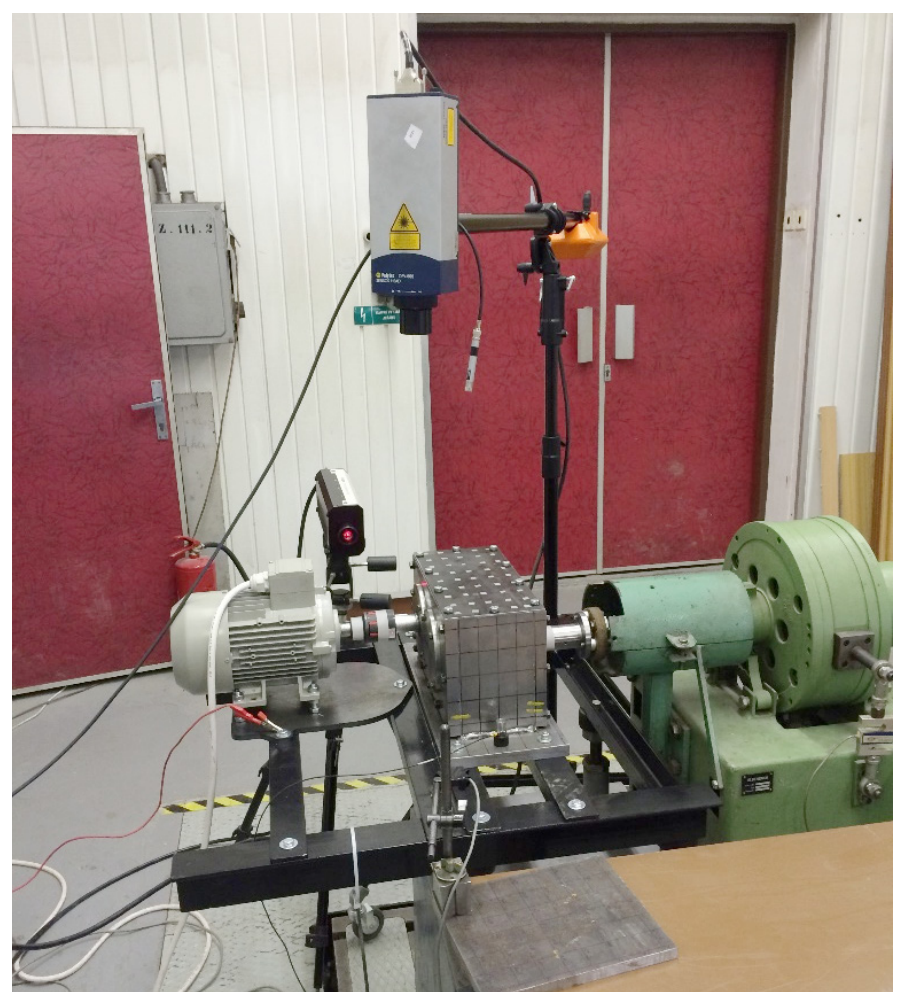

FIGURE 4: Single stage gearbox complete experimental setup OBRÁZEK 4: Celkové uspořádání měřícího řetězce experimentální prevodovky

the real involute shape originating from the precise $3 D C A D$ design. The basic profile characteristics are both in the case of the pressure and helix angle $20 \mathrm{deg}$, with module equal 4 . Detail of the gears is shown in the Figure 3.

The connection of gears and adequate shafts is represented by the very high spring stiffness in the model and this definition symbolizes real pressed contact. Moreover, the bearings definition is based on the stiffness and damping characteristics which stand for the real FE model. Therefore, the impact of the rolling elements is neglected.

\section{MEASUREMENT TECHNIQUES}

The measurement of the gearbox is performed on the assembled stage where the driven propulsion is secured by the electromotor and a brake torque on the output side is given by the dynamometer. Such an arrangement enables to fully control both the angular speed and the induced torque, simultaneously. As for the velocity amplitude measurement, it needs to be performed in a contactless form. Relatively thin cover $(3 \mathrm{~mm})$ of the gearbox housing is very sensitive to any additional mass, therefore the usual method using accelerometers is inadequate. Velocity limit $50 \mathrm{~mm} . \mathrm{s}-1$ for the laser vibrometer is sufficient, when considering real excitation. The complete experimental apparatus is presented in the Figure 4.

The experiment itself is, theoretically, conducted as a sweep rundown from $3000 \mathrm{~min}^{-1}$ to $0 \mathrm{~min}^{-1}$. Using the electromotor as a powering device appears to be a limitation. Braking torque of the dyno is held on the constant value $10 \mathrm{~N} . \mathrm{m}$. A small slip, characteristic for the asynchronous electromotor, allows to reach only $2500 \mathrm{~min}^{-1}$, when the torque is applied. Bottom limit is approx. around $500 \mathrm{~min}^{-1}$ because the nominal asynchronous motor power is only $3 \mathrm{~kW}$. Gearbox housing vibrations are measured in several singular points on the upper housing cover in form of the surface normal velocity.
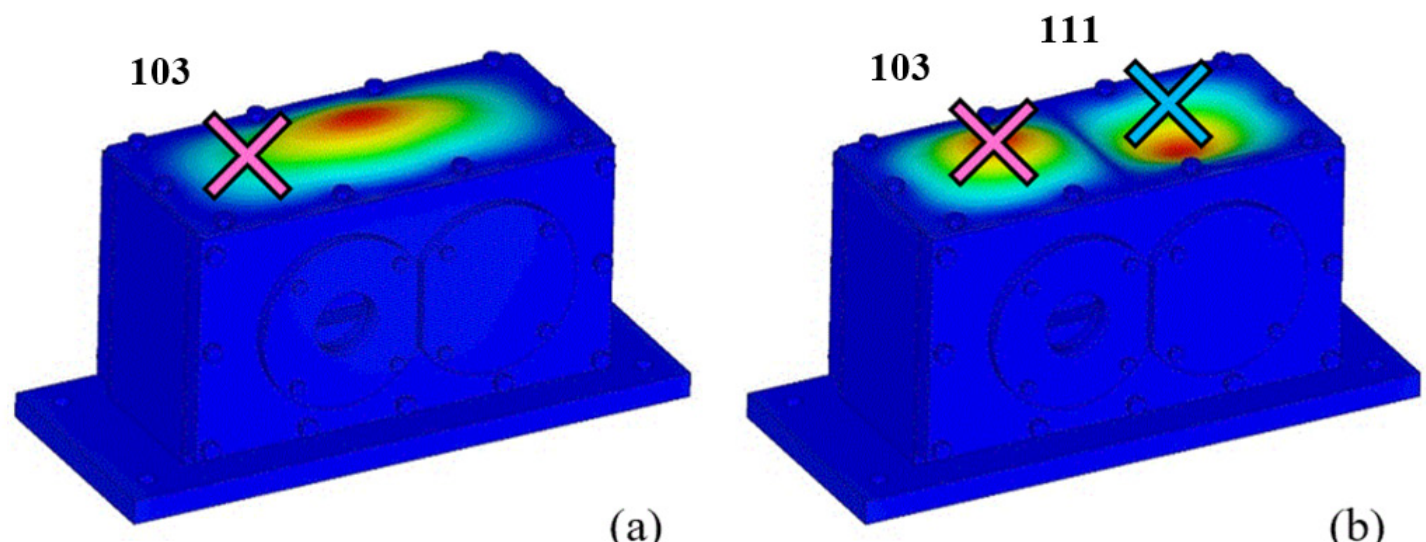

(a)

(b)

FIGURE 5: First (a) and second (b) mode shape of the gearbox housing with highlighted measured point on the surface OBRÁZEK 5: První (a) a druhý (b) vlastní tvar kmitání skříně převodovky spolu se zaznačeným měřícím bodem na povrchu 


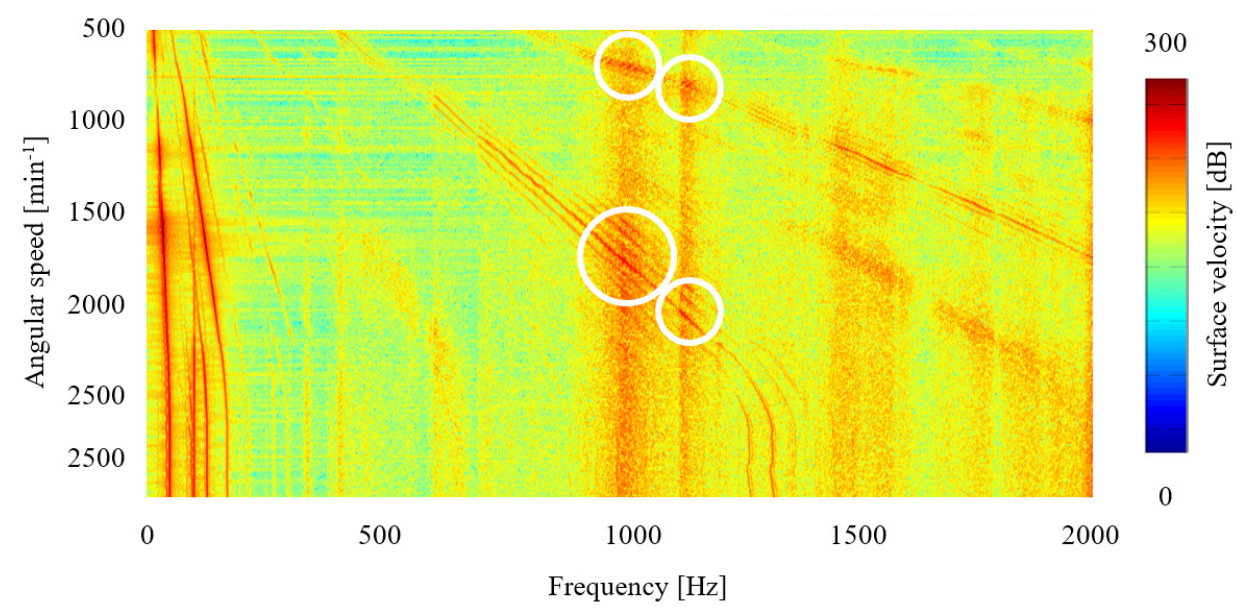

FIGURE 6: Surface normal velocity measurement at the previously specified location point 103 OBRÁZEK 6: Normálová rychlost povrchu při experimentu v definovaném bodě 103

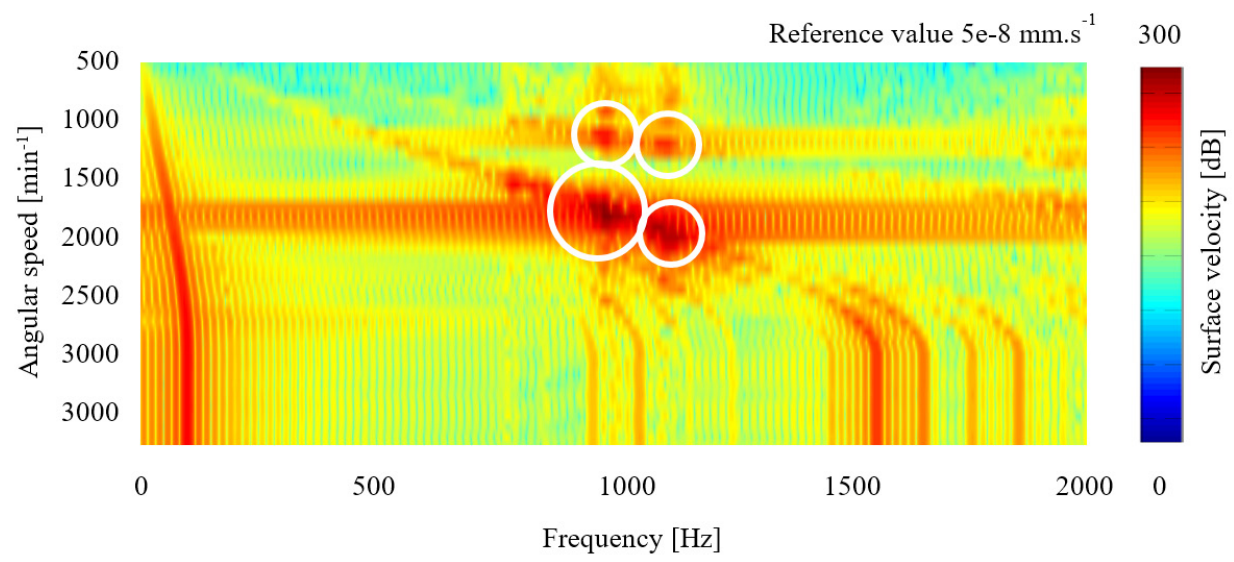

FIGURE 7: Surface normal velocity simulation at the same previously specified location point 103 OBRÁZEK 7: Normálová rychlost povrchu při simulaci v definovaném bodě 103

\section{RESULTS}

Comparison of the measurement and the simulation, inall, indicates good correlation, especially in the system resonances. All the amplifications when the gear meshing and natural frequency of the gearbox housing crosses each other are clearly visible on both waterfall diagrams in the Figures 6 and 7 (see white (highlights). Further investigation of the modal shapes can confirm that excited is really the same resonance.

An appropriate behavior of the reduced flexible body is essential for the right simulation results. The experiment proved that not all the housing mode shapes are affecting the final model dynamic behavior, nor on the whole surface. The chosen point is located out of the geometrical center of the upper housing cover and in this location the influence of the first mode shape at natural frequency $850 \mathrm{~Hz}$ disappears. The main excitation is activated when reaching the second mode shape at natural frequency $1000 \mathrm{~Hz}$. Differences in the mentioned mode shapes, together with the precise point 103 location are shown in the Figure 5.

A confirmation that the excited resonance in the measurement around $1000 \mathrm{~Hz}$ is really the second mode shape is done through the phase comparison. Helpful is the point 111 on the opposite side of the center, where the velocity vector is moved by 180 degrees. Divisions of the meshing frequency in the waterfall diagrams appear in the steady state of the run-up cycle. They are typical for the presence of the variable input rotational speed, also the imbalance influences this partial harmonics.

\section{CONCLUSION}

The presented computational model shows high potential in vibration solution in the whole transmission operational range. Comparison of the current MBS model with the measurement 
indicates good results in resonance stages. For possible further noise evaluation are, especially, these resonance amplifications the most problematic parts. Therefore, if the highest sound power or sound pressure level is intended to be quantified, the presented MBS model should be sufficient for such a prediction.

A difference in the range of up to $200 \mathrm{~Hz}$ is caused by the different gearbox drive. In the measurement a three-phase asynchronous electromotor is used, meanwhile the simulation is conducted with application of the sinusoidal varying rotational speed close to the characteristic of the four-cylinder internal combustion engine. Presence of the pole couples and slight imbalance in the system, simultaneously, create several low order lines instead of the single robust line, representing sinusoidal varying rotational speed.

Dynamic behavior, in-all, is highly dependent on the damping coefficients. Even though the structural damping is evaluated by the experimental modal analysis firstly and verified on the harmonic simulation vs. experiment secondly, there are still many influencing damping parameters assessed. For instance, the damping of the gear meshing and EHD contact which experimental verification is much more demanding. Together with improving manufacturing tolerances of the experimental gearbox, the model should be able to cover dynamics in all frequency and angular speed ranges.

\section{ACKNOWLEDGEMENT}

The research leading to these results has received funding from the Ministry of Education, Youth and Sports under the National Sustainability Programme I (Project L01202). This support is gratefully acknowledged.

\section{REFERENCES}

[1] Tuma J. Gearbox Noise and Vibration Prediction and Control, International Journal of Acoustics and Vibration, Vol. 14, Issue 2, 2009, pp.1-11. ISSN 1027-5851

[2] Loutas T.H., Sotiriades G., Kalaitzoglou I., Kostopoulos $V$. Condition monitoring of a single-stage gearbox with artificially induced gear cracks utilizing on-line vibration and acoustic emission measurements, Applied Acoustics, 70, 2009, pp.1148-1159. ISSN 0003-682X.

[3] Sawalhi N., Randall R.B. Simulation of the vibrations produced by extended bearing faults in gearboxes, Proceedings of First Australasian Acoustical Societies' Conference, Christchurch, New Zealand, 2006, p.541548. ISBN 978-0-909882-25-9.

[4] Barthod M., Hazne B., Tebec J.-L., Pin, J.-C. 2007. Experimental study of gear rattle excited by a multi- harmonic excitation, Applied Acoustics, 68, 2007, p.1003 - 1025. ISSN 0003-682X.

[5] BOZCA M., FIETKAU P. Empirical model based optimization of gearbox geometric design parameters to reduce rattle noise in an automotive transmission, Mechanism and Machine Theory, Vol. 45, Issue 11, 2010, p. 1599-1612. ISSN 0094-114X.

[6] BYRTUS M., ZEMAN V. Modelling and vibration of gear drive systems influenced by real face width, Journal of Mechanics Engineering and Automation, 3, 2013, p. 721-730. ISSN 2163-2405.

[7] Novotny P., Pistek V. New Efficient Methods for Powertrain Vibration Analysis, Proceedings of the Institution of Mechanical Engineers, Part D, Journal of Automobile Engineering, 2010. p.1377-1388. ISSN 09544070.

[8] CRAIG, R., BAMPTON, M. Coupling of substructures for dynamic analyses, AIAA Journal, Vol. 6, No. 7, 1968, p. 1313-1319.

[9] FERNÁNDEZ A., IGLESIAS M., DE-JUAN A., GARCIA P., SANCIBRIÁN R., VIADERO F. Gear transmission dynamic: Effect of tooth profile deviations and support flexibility. Applied Acoustics, Vol. 77, 2014, p. 138-149. ISSN 0003-682X.

[10]YONGXIANG L., LIHONG J., WENQUAN S., LIWEN N., YOUJIA Z. An efficient optimal design methodology for abnormal noise control of automobile transmission in the neutral idle condition. Journal of Vibroengineering, Vol. 16, Issue 1, 2014, p. 351-359. ISSN 1392-8716.

[11]Ashwani K., Himanshu J., Rajat J., Pravin P.P. Free Vibration and Material Mechanical Properties Influence Based Frequency and Mode Shape Analysis of Transmission Gearbox, Procedia Engineering 97, 2014, p. 1097-1106.

[12] Andersson A., Vedmar L. A dynamic model to determine vibrations in involute helical gears, Journal of Sound and Vibration, 260, 2003, p.195-212. ISSN 0022-460X.

[13] Lin T., Ou H., Li R. A finite element method for 3D static and dynamic contact/impact analysis of gear drives, Computer Methods in Applied Mechanics and Engineering, 196, 2007, p. 1716-1728. ISSN 0045-7825.

[14]MAZEIKA P., DIDZIOKAS R., BARZDAITIS V., BOGDEVICIUS M. Dynamics and reliability of gear driver with antifriction bearings, Journal of Vibroengineering, Vol. 10, Issue 2, 2008, p. 217-221. ISSN 1392-8716. 